\title{
Plasma xanthine levels in low birthweight infants treated or not treated with theophylline
}

\author{
JEAN-LOUIS BRAZIER, HUBERT RENAUD, BRUNO RIBON, AND BERNARD L. SALLE
}

Laboratoire de Pharmacologie Clinique et Service de Néonatologie, Hôpital Edouard-Herriot, Lyon

SUMMARY The use of theophylline in the management of apnoea in the newborn was studied in 33 preterm infants. Infants received a dose of $3 \mathrm{mg} / \mathrm{kg}, 13$ of them every six hours, the remaining 20 every eight hours. All the infants had significantly fewer apnoeic episodes. In a pharmacokinetic study, the half life of theophylline was $30.3 \pm 7.2$ hours and the clearance rate was $23.9 \pm 5.06$ $\mathrm{ml} / \mathrm{kg}$ per hour (means and SD). The plasma theophylline level remained constant at between 13 and 15 $\mathrm{mg} / \mathrm{l}$ from the 5 th day of treatment but, at the same time, the plasma levels of caffeine rose to a mean level of $4.4 \mathrm{mg} / \mathrm{l}$. Caffeine was detectable in plasma at birth, and in preterm infants not receiving theophylline; plasma levels of caffeine tended to be similar to the levels in their mothers' milk. These observations have led to clear conclusions on the optimum timing and dosage of theophylline, and on the need to monitor plasma levels of both theophylline and caffeine in newborn infants treated with theophylline.

About one-quarter of newborn babies $<2500 \mathrm{~g}$ have an apnoeic episode during the first 10 days of life (Daily et al., 1969); repeated episodes can lead to brain damage because of hypoxia and acidosis (Bacola et al., 1966; Alden et al., 1972). We do not yet know the pathogenesis of apnoea: several factors seem to operate, especially an alteration in the sensitivity of central nervous receptors to hypoxia and (or) hypercapnia due to cerebral immaturity (Parmelee et al., 1972; Rigatto and Brady, 1972; Kattwinkel, 1977). Kuzemko and Paala (1973) were the first to treat apnoea in premature infants with xanthines, and this treatment has been shown to be successful (Shannon et al., 1975; Uauy et al., 1975; Aranda et al., 1976; Bednarek and Roloff, 1976; Giacoia et al., 1976; Demarquez et al., 1977).

The aim of this study is to present our results on the use of theophylline in the treatment of premature apnoea with particular reference to the pharmaco-

\footnotetext{
Laboratoire de Pharmacologie Clinique, Unité INSERM U80, and Neonatal Department, Hôpital Edouard-Herriot JEAN-LOUIS BRAZIER, assistant, Laboratoire de Pharmacologie Clinique

HUBERT RENAUD, assistant, Service de Néonatologie

BRUNO RIBON, assistant, Laboratoire de Pharmacologie Clinique

BERNARD L. SALLE, professor, Service de Néonatologie
}

kinetic study of theophylline and caffeine. It is well known that caffeine, like theophylline, prevents apnoea but is equally dangerous; however, this study shows that caffeine is always present in the plasma of premature infants treated only with theophylline.

\section{Material and methods}

In the 7 months from 1 March to 31 October 1977, we treated 33 infants for recurrent apnoea, using theophylline (1-3 dimethylxanthine). Recurrent apnoea was definied as cessation of breathing for more than 25 seconds with bradycardia, with or without cyanosis, occurring at least 3 times a day.

The mean birthweight was $1450 \pm 281 \cdot 5 \mathrm{~g}$ (SD) (900-2100) and mean gestational age, assessed by the Dubowitz score system (Dubowitz et al., 1970), $33 \cdot 6 \pm 2 \cdot 3$ weeks (27-37). The mean age when theophylline was first given was $2 \cdot 9 \pm 2$ days and the duration of this treatment was between 5 and 35 days (mean 15.2). In addition to the recurrent apnoeic spells, concomitant diseases were respiratory distress syndrome (2), and Klebsiella septicaemia (treated with gentamicin) (2). Clinical and laboratory evidence of metabolic abnormalities (e.g. hypoglycaemia or hypocalcaemia) or other correctable causes of apnoea was absent at the time of starting treatment. None of the infants was treated 
with continuous distending airway pressure (positive pressure or negative pressure respirator).

The baby was placed in an incubator with servo controlled temperature; apnoea was observed visually or by the use of an apnoea monitor (Infants Sentry Stolting, USA) adjusted to signal after 9 seconds of apnoea. The heart rate was monitored by cardioscope, and an alarm signalled when the rate fell below 80 . The respiratory rate was recorded hourly by inspection during the critical phase (1 to 3 days) and thereafter every three hours. Arterial blood-gases and $\mathrm{pH}$ were checked regularly every 3 to 6 hours during the first day of life by means of an arterial catheter; thereafter arterialised blood for measuring $\mathrm{pH}$ and $\mathrm{PCO}_{2}$ was obtained daily by heel pricks, or more often if clinically indicated.

Theophylline dissolved in $10 \%$ alcohol in a concentration of $5 \mathrm{mg} / \mathrm{ml}$ was administered by nasogastric tube. Initially, 13 newborn babies received a dose of $3 \mathrm{mg} / \mathrm{kg}$ every 6 hours, but when we found that xanthine bases tended to accumulate in the plasma the dose was changed and 20 infants received the same dose every 8 hours. (No infant received caffeine.) A single IM injection of phenobarbitone $(10 \mathrm{mg} / \mathrm{kg})$ was given to each baby immediately after birth to diminish neonatal jaundice (Salle et al., 1977).

Plasma levels of theophylline and caffeine were measured on the mornings of the 1st, $2 \mathrm{nd}$, 3rd, 5 th, and 11th days of theophylline treatment, and then every 3 or 4 days. The blood was taken by heel prick 2 hours after administration of the drug. In 10 infants the levels of theophylline and caffeine were measured at periods of one hour, and then 5 , 6 , 7, and 8 hours immediately after the oral administration of $3 \mathrm{mg} / \mathrm{kg}$ theophylline on the 2nd day of treatment to estimate the clearance rate of theophylline and caffeine. In 20 infants, the clearance and half life of plasma theophylline were measured.

In 55 preterm and term newborn babies, the plasma level of caffeine was measured at birth and before any drug treatment; mean birthweight was $1757 \pm$ $494 \cdot 6 \mathrm{~g}$ (SD) and mean gestational age was $35 \pm 3 \cdot 3$ weeks.

The level of caffeine was also measured in the plasma of 6 breast-fed babies not treated by theophylline and in their mothers' milk for 6 days. Mean birthweight was $1906 \pm 118$ and mean gestational age $34 \cdot 8 \pm 1 \cdot 8$ weeks.

Plasma theophylline and caffeine levels were measured in $20 \mu \mathrm{l}$ plasma by gas liquid chromatography (GLC) using nitrogen-specific detection (Ribon et al., 1979). The method allows the simultaneous measurement of theophylline, caffeine, and phenobarbitone (Fig. 1). The three drugs are extracted

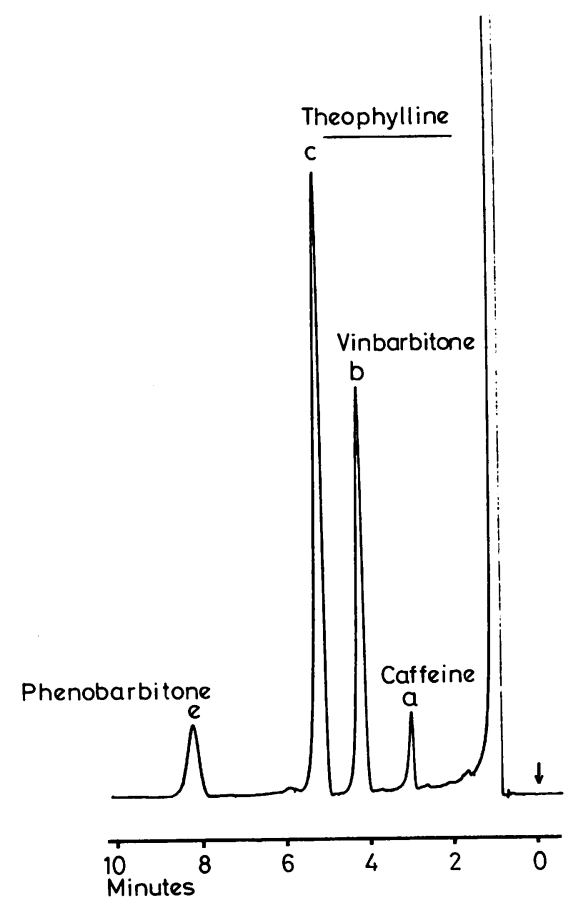

Fig. 1 Chromatogram of plasma from a preterm infant.

from plasma or whole blood with a mixture of chloroform and isopropanol $(95.5 \mathrm{v} / \mathrm{v})$ in a buffered medium at $\mathrm{pH} 5 \cdot 2$. The pentyl derivatives of the extracted molecules are separated by GLC on a column coated with $3 \%$ OV17 on chromosorb W AW D M C S. The quantitative minimum sensitivity is $<0.5 \mu 1 / \mathrm{ml}$ for the three drugs.

The bio-availability of the solution of theophylline (in ethanol/water $10 \% \mathrm{v} / \mathrm{v}$ ) is about $100 \%$. The drug is administered by doses of $3 \mathrm{mg} / \mathrm{kg}$ every 8 hours, the pharmacokinetic parameters may be calculated from the following equation.

$$
P_{s s}=\frac{\text { Do }}{K_{e} V_{f} T}(1) \text {, where }
$$

$\mathbf{P}_{\mathrm{ss}}=$ plasma level at steady state, Do $=$ administered dose, $K_{e}=$ elimination rate constant, $V_{f}=$ volume of distribution, $\mathrm{T}=$ time interval between two doses.

The total clearance is given by the relation

$$
\mathrm{Cl}=\mathrm{K}_{\mathrm{e}} \mathrm{V}_{\mathrm{f}}(2) \text {, }
$$

and combining equations (1) and (2),

$$
\mathrm{Cl}=\mathrm{K}_{\mathrm{e}} \mathrm{V}_{\mathrm{f}}=\frac{\text { Do }}{\mathrm{P}_{\mathrm{ss}} \mathrm{T}} \text { (3) }
$$


Clearance may be calculated from the plasma level at steady state after 5 days' treatment with theophylline. For each baby the dose (Do) and time interval $(\mathrm{T})$ are known, allowing the clearance value to be calculated from equation (3). During the first reaction, the constant elimination rate is related to half life $\left(t_{i}\right)$ by the equation,

$$
K_{e}=\frac{0.693}{t_{\frac{1}{2}}}
$$

The half life was calculated by the fall in plasma level of theophylline after oral administration. The volume of distribution $\left(V_{f}\right)$, is then given by,

$$
\mathrm{V}_{\mathrm{f}}=\frac{\mathrm{Cl} \times \mathrm{t}_{\frac{1}{2}}}{0.693}
$$

\section{Results}

Out of 33 treated infants 18 had no further apnoea. Of the 15 remaining infants in this group, none required to be ventilated for apnoeic spells. Fig. 2 shows the course of apnoeic spells after birth in these 15 infants. The treatment was stopped in one baby because of tachycardia and at that time the plasma level of theophylline was $24 \mathrm{mg} / \mathrm{l}$.

Pharmacokinetic study. In 20 infants, the mean clearance was $23.96 \pm 5.06 \mathrm{ml} / \mathrm{kg}$ (SD) per hour. The half life was $30 \cdot 3$ hour $\pm 7 \cdot 2$, the distribution of the volume of theophylline was $1.03 \pm 0.2$ $1 / \mathrm{kg}$. The absorption of theophylline was rapid because the half life is long and plasma levels remained fairly constant between each oral adminis-

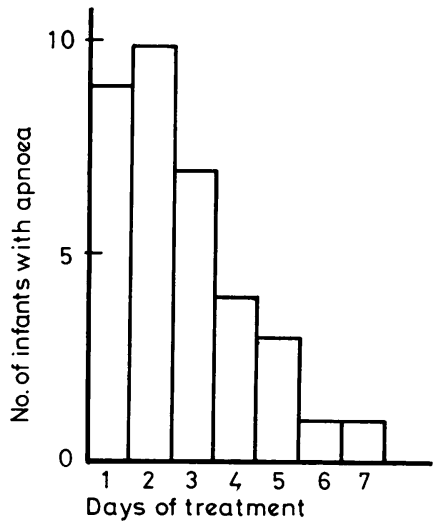

Fig. 2 Number of infants (out of 33) who had apnoeic spells after the 1st day of treatment. tration (Fig. 3); plasma levels were measured at various times after oral administration so that the absorption of the drug could be studied.

With the dose used, the mean plasma level of theophylline rose rapidly to plateau between 13 and $15 \mathrm{mg} / 1$ from the 5 th day of treatment. The plasma level was maintained within these two limits with a

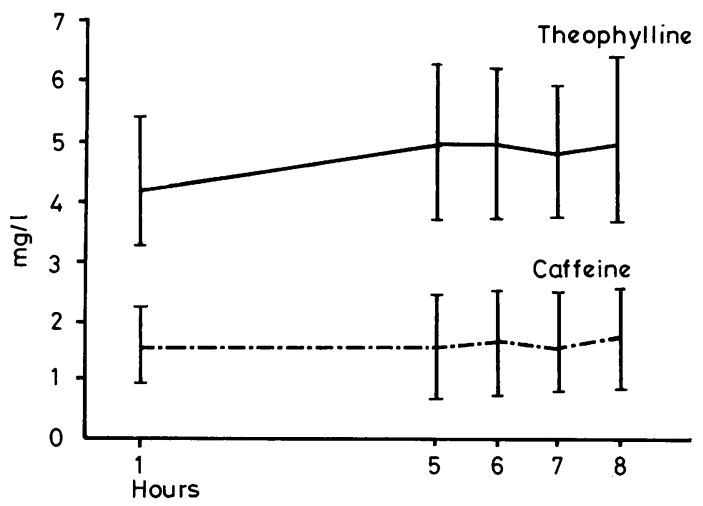

Fig. 3 Course of plasma theophylline levels in 10 infants after an oral dose of $3 \mathrm{mg} / \mathrm{kg}$ (mean and SD). Theophylline was given every 8 hours.

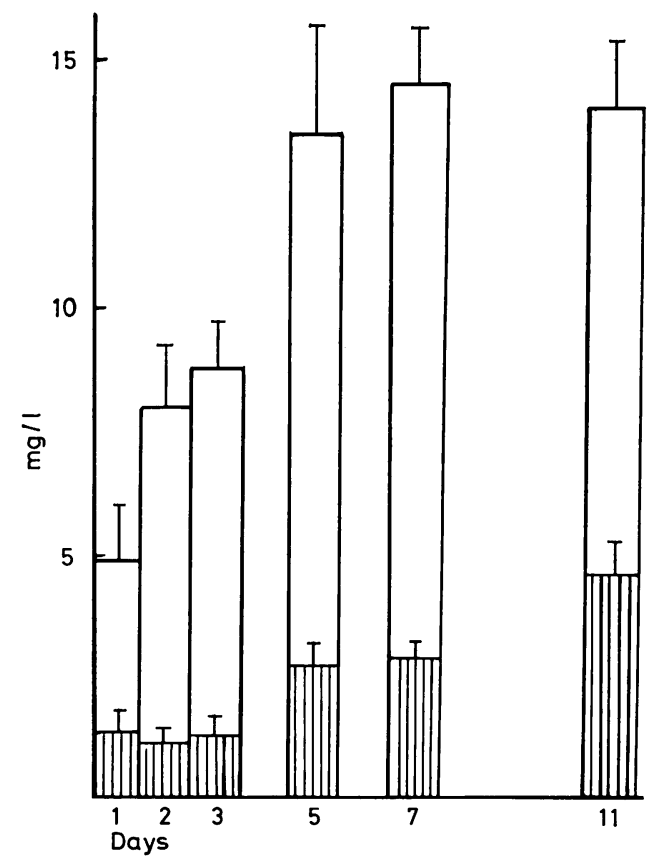

Fig. 4 Course of xanthine base levels (theophylline, blank column; caffeine, hatched column) in 33 infants (mean and $S D$ ). 
dose of $3 \mathrm{mg} / \mathrm{kg} \mathrm{8}$-hourly. At the same time, the plasma level of caffeine rose to a mean level of 4.4 $\mathrm{mg} / \mathrm{l}$ by the 11 th day of treatment. The total mean level of xanthines (caffeine + theophylline) was between $15 \cdot 7$ and $18 \mathrm{mg} / 1$ (Fig. 4).

The plasma levels of caffeine and theophylline correlated (104 measurements, $\mathrm{r} 0.56, \mathrm{P}<0.01)$ (Fig. 5).

\section{Plasma levels of caffeine at birth}

Caffeine readily crosses the placenta (Parsons et al., 1976). The level of caffeine at birth (age 1-2 hours), is shown in the Table. $76 \%$ of infants studied had detectable caffeine in the plasma (Table).
Table Plasma levels of caffeine at birth (55 infants studied)

\begin{tabular}{|c|c|}
\hline Plasma levels of caffeine $(\mathrm{mg} / \mathrm{l})$ & \\
\hline$m g / l$ & 10 \\
\hline $\begin{array}{l}0 \\
\text { Between } 0 \text { and } 1 \\
1 \text { and } 2 \\
2 \text { and } 3 \\
3 \text { and } 4 \\
4 \text { and } 5 \\
5 \text { and } 6\end{array}$ & $\begin{array}{l}23.63 \\
20 \\
29.09 \\
16 \cdot 36 \\
3.63 \\
3.63 \\
3.63\end{array}$ \\
\hline
\end{tabular}

Infant plasma and maternal milk levels of caffeine There was a significant correlation between the two levels against time (Fig. 6). Low levels of caffeine
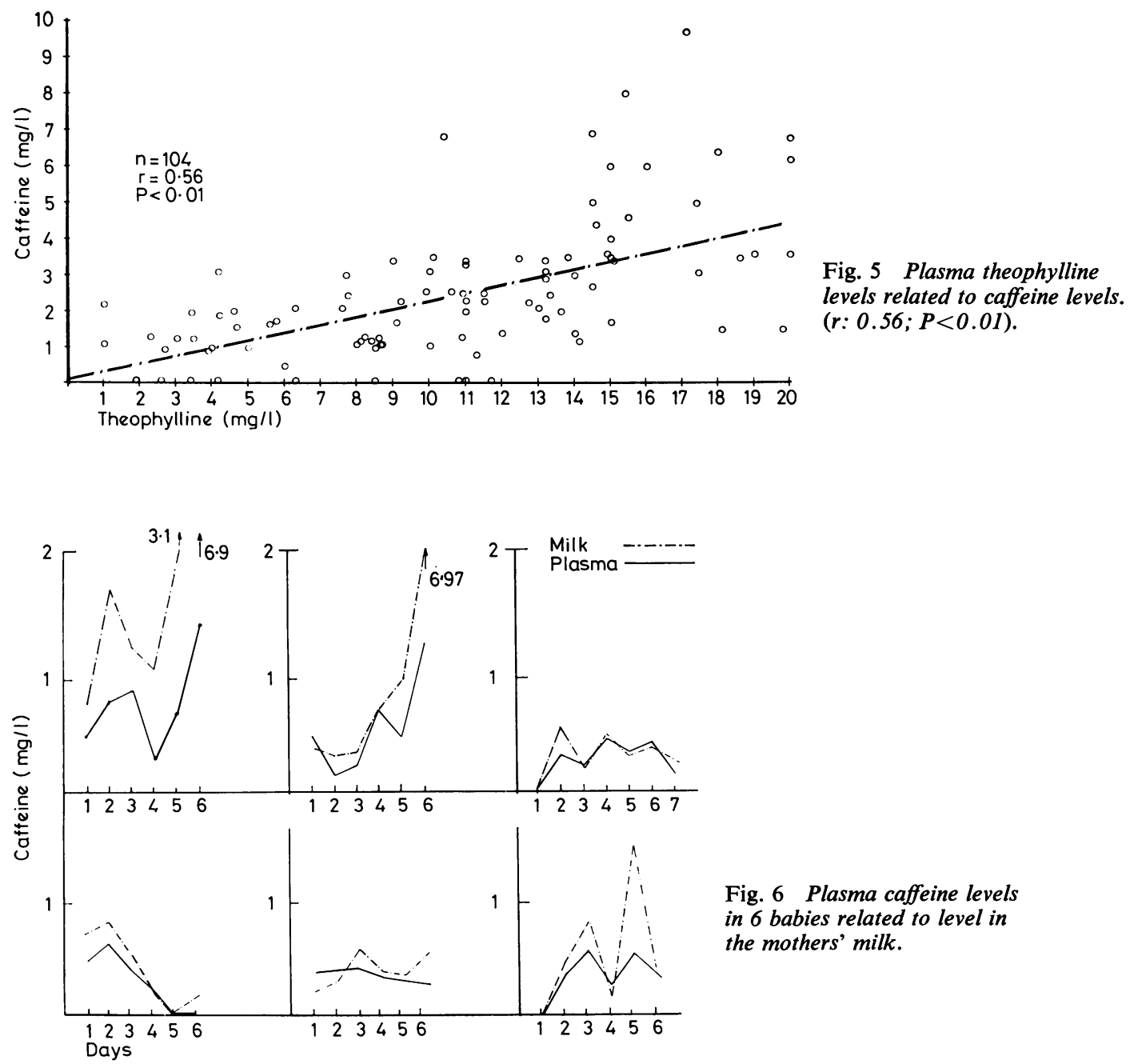

Fig. 6 Plasma caffeine levels in 6 babies related to level in the mothers' milk. 
in maternal milk were associated with undetectable levels in the infants' plasma, while high levels in the maternal milk gave a raised level in the child. In this study, the infants were aged either $8-15$ or $15-21$ days. Results showed that diet alone could not have been responsible for the accumulation of caffeine in the plasma up to levels of $1.5 \mathrm{mg} / \mathrm{l}$, although the half life of this substance is very long in the newborn (Aranda et al., 1977a).

\section{Discussion}

Our study confirms results on the pharmocokinetics of theophylline in term infants; we found it had a long half life, the clearance rate being $23.96 \pm$ $5.06 \mathrm{ml} / \mathrm{kg}$ per hour. Our results were slightly higher than some others: Aranda et al. (1976), measuring theophylline in total blood, found a clearance of $17.6 \mathrm{ml} / \mathrm{kg}$ per hour, Giacoia et al. (1976), a clearance of $30 \mathrm{ml} / \mathrm{kg}$ per hour. Our values were closer to those of Demarquez et al. (1977), 23.6 \pm $9.41 \mathrm{ml} / \mathrm{kg}$ per hour.

In order to maintain a minimum level of theophylline of $8 \mathrm{mg} / 1$ and to avoid exceeding $15 \mathrm{mg} / 1$ (Aranda et al., 1976; Demarquez et al., 1977), we now give $3 \mathrm{mg} / \mathrm{kg}$ theophylline every 8 hours, the same dose recommended by Shannon et al. (1975) and Uauy et al. (1975). The plasma level of theophylline was kept low, so decreasing the possible side effects-such as sleep disturbance, diuresis, and failure to gain weight. Nevertheless, it is important to check the plasma level of theophylline every three days, because the clearance rate varies between different infants (from 15.5 to $34.5 \mathrm{ml} / \mathrm{kg}$ per hour). We had no complications in our babies except in one (see Results).

By observing the plasma level of theophylline we have developed a new method of treatment. In order to increase the plasma level of theophylline rapidly on the first day and then maintain a plateau below $15 \mathrm{mg} / \mathrm{l}$, we give a high oral dose of $6 \mathrm{mg} / \mathrm{kg}$ initially.

It is known that the toxicity and pharmocological activity of caffeine are similar to those of theophylline. Some have advocated the use of caffeine in the prevention and treatment of apnoea in the preterm infant (Aranda et al., 1977a, b). $76 \%$ of newborn babies had detectable levels of caffeine at birth; this fact could possibly explain why apnoeic spells often start after the 2 nd day of life in preterm infants. In the theophylline-treated infants, the plasma level of caffeine rose to about $5 \mathrm{mg} / \mathrm{l}$; thus it seems important to measure the levels of both theophylline and caffeine in order to know the total level of xanthine bases in infants receiving either theophylline or caffeine.
The presence of caffeine in the plasma of infants receiving only theophylline was surprising. It is possible that the baby had received caffeine from the mother: we have shown that in preterm infants not treated with theophylline, the plasma levels of caffeine were similar to those in their mothers' milk, although in no baby did the plasma level of caffeine exceed $1.5 \mathrm{mg} / \mathrm{l}$. In the theophylline-treated preterm infants, the plasma levels of caffeine were higher and the mothers' milk alone could not have been responsible for the accumulation of caffeine.

Another possible explanation is biochemical. It is known that in adults, caffeine is metabolised by demethylation to give theophylline. The inverse process (i.e. methylation in $\mathrm{N}_{7}$ of theophylline) might exist in the infant; we are testing this hypothesis by means of molecules labelled with stable isotopes. The fact that phenobarbitone was given at birth to these preterm infants and that a dose of phenobarbitone increases liver enzyme activity could be relevant.

Theophylline is useful for treating or preventing apnoeic spells in the preterm infant but, because of the varying clearance rate in individuals, it should be given in low doses and plasma levels should be checked regularly; as there is a parallel accumulation of caffeine in the plasma, the plasma level of caffeine should also be checked.

We thank the nursing staff for their co-operation, Mrs Cascales for secretarial assistance, and $\mathrm{Dr}$ Pamela A. Davies (London) for suggestions.

\section{References}

Alden, E. R., Mandelkorn, T., Woodrum, D. E., Wennberg, R. P., Parks, C. R., and Hodson, A. (1972). Morbidity and mortality of infants weighing less than 1000 grams in an intensive care nursery. Pediatrics, 50, 40-49.

Aranda, J. V., Sitar, D. S., Parsons, W. D., Loughnan, P. M., and Neims, A. H. (1976). Pharmacokinetic aspects of theophylline in premature newborns. New England Journal of Medicine, 295, 413-416.

Aranda, J. V., Gorman, W., Bergsteinsson, H., and Gunn, T. (1977a). Efficacy of caffeine in treatment of apnea in the low birthweight infant. Journal of Pediatrics, 90, 467-472.

Aranda, J. V., Gorman, W., Outerbridge, E. W., and Neims, A. H. (1977b). Pharmacokinetic disposition of caffeine in premature neonates with apnea (abstract). Pediatric Research, 11, 414.

Bacola, E., Behrle, F. C., de Schweinitz, L., Miller, H. C., and Mira, M. (1966). Perinatal environmental factors in late neurogenic sequelae. I. Infants having birth weights under 1500 grams. American Journal of Diseases of Children, 112, 359-368.

Bednarek, F. J., and Roloff, D. W. (1976). Treatment of apnea of prematurity with aminophylline. Pediatrics, 58, 335-339.

Daily, W. J. R., Klaus, M., and Meyer, H. B. P. (1969). Apnea in premature infants: monitoring, incidence, heart rate changes, and an effect of environmental temperature. Pediatrics, 43, 510-518. 
Demarquez, J. L., Philippe, J. Cl., Paty, J., Babin, J. P., Seguin, G., and Martin, L. L. (1977). Les apnées du nouveau-né. Médicine Infantile, 6, 645-663.

Dubowitz, L. M. S., Dubowitz, V., and Goldberg, C. (1970). Clinical assessment of gestational age in the newborn infant. Journal of Pediatrics, 77, 1-10.

Giacoia, G., Jasko, W. J., Menke, J., and Koup, J. R. (1976). Theophylline pharmacokinetics in premature infants with apnea. Journal of Pediatrics, 89, 829-832.

Kattwinkel, J. (1977). Neonatal apnea: pathogenesis and therapy. Journal of Pediatrics, 90, 342-347.

Kuzemko, J. A., and Paala, J. (1973). Apnoeic attacks in the newborn treated with aminophylline. Archives of Disease in Childhood, 48, 404-406.

Parmelee, A. H., Stein, E., and Harris, M. A. (1972). Maturation of respiration in prematures and young infants. Neuropediatrie, 3, 294-304.

Parsons, W. D., Aranda, J. V., and Neims, A. H. (1976). Elimination of transplacentally acquired caffeine in full term neonates (abstract). Pediatric Research, 10, 333.

Ribon, B., Brazier, J. L., Bannier, A., and Pinatel, H. (1979). Microdosage simultané de la théophylline, de la caféine et du phénobarbital dans le sang par chromatographie en phase gazeuse. Clinica chimica acta, in press.

Rigatto, H., and Brady, J. P. (1972). Periodic breathing and apnea preterm infants. II. Hypoxia as a primary event. Pediatrics, 50, 219-227.

Salle, B., Pasquer, P., Desebbe, Cl., Rouzioux, J. M., and Barouty, B. (1977). Phenobarbital in prophylaxis of neonatal jaundice. Helvetica paediatrica acta, 32, 221-226.

Shannon, D. C., Gotay, F., Stein, I. M., Rogers, M. C.,Todres, I. D., and Moylan, F. M. B. (1975). Prevention of apnea and bradycardia in low birthweight infants. Pediatrics, 55, 589-594.

Uauy, R., Shapiro, D. L., Smith, B., and Warshaw, J. (1975). Treatment of severe apnea in prematures with orally administered theophylline. Pediatrics, 55, 595-598.

Correspondence to Dr B. Salle, Neonatal Department, Hôpital Edouard-Herriot, Place d'Arsonval, 69374 Lyon Cedex 2, France.

Received 22 May 1978 